\title{
Youth identity and risk
}

\author{
Wendy Beatriz Mansilla Figueroa
}

Investigador avalado por el Instituto de Investigaciones Políticas y Sociales de la Escuela de Ciencia Política. Proyecto de investigación financiado por la Dirección General de Investigación. Universidad de San Carlos de Guatemala

Autora a la que se dirige la correspondencia: wendy.mansilla@gmail.com

\section{Resumen}

I a presente ponencia constituye un resumen de los resultados emanados del proyecto de investigación "ConsLtrucción de las identidades juveniles en espacios de riesgo" implementado en el año 2016, el método de investigación utilizado fue el cualitativo con alcance comparativo; Se utilizaron tres técnicas de investigación cualitativa que permitieron contar con la información necesaria para el análisis. El objetivo de la realización de este estudio, se enfocó en la caracterización de las formas en que los procesos de socialización construyen las identidades juveniles. Dentro de este proceso se consideró importante ahondar en la incidencia derivada de las problemáticas, conflictos y situaciones de violencia inmersos en los procesos de socialización y su influencia en la construcción de su identidad. Este estudio fue desarrollado en cuatro áreas del Departamento de Guatemala: dos en el municipio de Villa Nueva y las restantes en el municipio de Santa Catarina Pinula. En el caso de Villa Nueva coexisten áreas con elevados niveles de pobreza y falta de servicios básicos y, por otra parte, espacios con niveles de desarrollo económico medio que viven en los límites urbanos, este es el caso de la zona 6.

Palabras claves: Violencia, comunidad, socialización, familia, jóvenes.

\section{Abstract}

$\mathrm{T}$ his paper is a summary of the results of the research project "Construction of juvenile identities in risk areas" implemented in 2016, the research method used Was the qualitative one with comparative scope; Three qualitative research techniques were used to provide the necessary information for the analysis. The objective of this study was to characterize the ways in which socialization processes construct youth identities. Within this process it was considered important to delve into the incidence derived from the problems, conflicts and situations of violence immersed in the socialization processes and their influence on the construction of their identity. This study was developed in four areas of the Department of Guatemala: two in the municipality of Villa Nueva and the remaining in the municipality of Santa Catarina Pinula. In the case of Villa Nueva, areas with high levels of poverty and lack of basic services coexist and, on the other hand, spaces with levels of average economic development that live in the urban limits, this is the case of zone 6 .

Key words: Violence, community, socialization, family, young people. 